\section{NACIONALIZACIÓN Y REPRESIÓN EN LA UNIVERSIDAD DE MAR DEL PLATA. EL CIERRE DE LAS CARRERAS DE CIENCIAS SOCIALES (1975-1977)}

GASTÓN JULIÁN GIL

Gastón Julián Gil es Investigador del CONICET y Profesor de la Universidad Nacional de Mar del Plata. e-mail: gasgil@mdp.edu.ar

\section{Resumen}

El proceso de nacionalización de la Universidad Provincial de Mar del Plata, que absorbió además a la Universidad Católica «Stella Maris», se produjo en el contexto de una profunda represión estatal y paraestatal. En ese marco, las carreras de ciencias sociales que, desde la última parte de los años sesenta, le habían dado vida a la Facultad de Humanidades de la casa de estudios estatal, fueron eliminadas completamente de la oferta curricular. Tras el cierre de inscripción de 1975, dos años más tarde, esa misma facultad sólo ofrecería aquellas carreras que se dictaban en su antecesora privada y confesional (historia, letras, geografía, inglés). Por ende, en este artículo se describe el contexto sociopolítico que enmarcó la vida universitaria de la época, pero muy especialmente se pone énfasis en las especificidades institucionales y el conjunto de actores en pugna en ese ámbito puntual. Así, las complejas disputas a nivel de la política provincial de Buenos Aires, los enfrentamientos dentro de la militancia del peronismo en la universidad y las propias características de Mar del Plata, constituyen algunos de los ejes más importantes del caso analizado.

\section{Summary}

The process by means of which the Provincial University of Mar del Plata was nationalized (absorbing as well the private Catholic University «Stella Maris») took place within a context of hard governmental and para-governmental repression. The degrees in social sciences (which had promoted the foundation of the Faculty of Humanities in the state university) were completely eliminated. After the closure of inscriptions in 1975, two years later this faculty would only offer the degree programs that had been developed in the catholic and private university: History, Literature, Geography, and English. This article accounts for the sociopolitical context of the university life of that period, and it focuses on specific institutional activities and contending actors in this concrete scenario. Some of the principal axes to be considered in the analyzed case are: (1) complex political disputes in the Province of Buenos Aires, (2) clashes within the peronist militancy in university, and (3) proper features of Mar del Plata City. 